\title{
Evaluation of the implementation of sexual and reproductive health actions in Primary Care: scope review
}

\author{
Avaliação de implantação das ações de saúde sexual e reprodutiva na Atenção Primária: \\ revisão de escopo

\section{Evaluación de implantación de acciones de salud sexual y reproductiva en la Atención Básica:} \\ revisión de escopo
}

\section{Carla Cardi Nepomuceno de Paiva ${ }^{1}$} Rosângela Caetano ${ }^{1}$ (1)

1. Universidade do Estado do Rio de Janeiro, Instituto de Medicina Social. Rio de Janeiro, RJ, Brasil.
Corresponding author:

Carla Cardi Nepomuceno de Paiva.

E-mail: carlacardiufjf@gmail.com

Submitted on 05/13/2019.

Accepted on 09/16/2019.

DOI: 10.1590/2177-9465-EAN-2019-0142

\begin{abstract}
Objective: To characterize researches that evaluate actions implemented with a focus on sexual and reproductive health; to describe factors that favor or hinder its application in Primary Health Care. Method: Scope review performed from the databases LILACS, MEDLINE, SCOPUS, Web of Science, CINAHL and POPLINE, and in the Brazilian Electronic Theses and Dissertations Digital Library. Data collected in January 2019 and analyzed according to the health evaluation literature. One reviewer performed the selection and extraction. Articles and academic research developed in the Brazilian scenario and published between January 1994 and January 2019 were included. Results: Of the 14 publications included, more than half corresponded to prenatal care and reproductive planning. The evaluation identified issues of context, and physical infrastructure influenced the implementation. Conclusion and implications for practice: Management and professional efforts are necessary for the implantation, sustainability, reformulation, and evaluation of these actions.
\end{abstract}

Keywords: Sexual and Reproductive Health; Primary Health Care; Health Evaluation.

\section{Resumo}

Objetivo: Caracterizar pesquisas de avaliação de implantação com alvo em ações de saúde sexual e reprodutiva e descrever fatores que favorecem ou obstaculizaram a sua implantação na Atenção Primária à Saúde. Método: Revisão de escopo realizada a partir das bases de dados LILACS, MEDLINE, SCOPUS, Web of Science, CINAHL e POPLINE e na Biblioteca Digital Brasileira de Teses e Dissertações. Dados coletados em janeiro de 2019 e analisados segundo a literatura de avaliação em saúde. Um revisor realizou a seleção e extração. Foram incluídos artigos e pesquisas acadêmicas desenvolvidas no cenário brasileiro e publicadas entre janeiro de 1994 e janeiro de 2019. Resultados: Das 14 publicações incluídas, mais da metade corresponderam aos cuidados pré-natais e ao planejamento reprodutivo. A avaliação identificou que questões do contexto e da estrutura física influenciaram na implantação. Conclusão e implicações para a prática: Esforços da gestão e dos profissionais são necessários para a implantação, manutenção, reformulação e avaliação dessas ações.

Palavras-chave: Saúde Sexual e Reprodutiva; Atenção Primária à Saúde; Avaliação em Saúde.

\section{RESUMEN}

Objetivo: Caracterizar investigaciones de evaluación de implantación con foco en acciones de salud sexual y reproductiva y describir factores que favorecen u obstaculizaron su implantación en la Atención Primaria a la Salud. Método: Revisión de escopo realizada a partir de las bases de datos LILACS, MEDLINE, SCOPUS, Web of Science, CINAHL y POPLINE y la Biblioteca Digita Brasileña de Tesis y Disertaciones. Datos recogidos en enero de 2019 y analizados según la literatura de evaluación en salud. Selección y extracción hecha por revisor. Se incluyeron artículos e investigaciones académicas desarrolladas en el escenario brasileño y publicadas entre enero 1994 y enero 2019. Resultados: De las 14 publicaciones incluidas, la mayoría correspondió a cuidados prenatales y planificación reproductiva. La evaluación identificó que cuestiones de contexto y estructura física influenciaron en la implantación. Conclusión e implicaciones para la práctica: Esfuerzos de la gestión y de los profesionales son necesarios para implantación, mantenimiento, reformulación y evaluación de esas acciones.

Palabras clave: Salud Sexual y Reproductiva; Atención Primaria a la Salud; Evaluación en Salud. 


\section{INTRODUCTION}

Meeting the health demands of the population with the intention of improving the quality of life is a matter of concern in all health systems, considering the high cost of health technologies and the scarcity of public resources. In the health field, evaluation is an important management and planning mechanism, contributing to the use of these public resources in the most correct, sustainable and effective way possible, in order to help formulators and managers to improve the implemented actions. ${ }^{1}$

The National Policy for Primary Care recommends the institutionalization of Primary Health Care (PHC) evaluation. ${ }^{2}$ In this care setting, actions to promote and prevent diseases in the context of sexual and reproductive health are considered one of its priority axes and, therefore, one of the responsibilities of those actors, especially in the municipal context.

Reproductive and sexual health, as a field of knowledge and practice, refers to expanded notions of health and to sexual and reproductive rights. ${ }^{3}$ Reproductive health implies autonomy, security and freedom in reproductive and sexual decisions, including the provision of health services, information and efficient and safe methods for its planning by men and women. ${ }^{4}$ The definition of sexual health as an ability to express and live sexuality without risk of disease, discrimination or violence is inserted in the context of reproductive health actions. ${ }^{4}$

The scope covered by sexual and reproductive health actions is quite broad and should include clinical care, counseling and educational activities, extending longitudinally to prenatal, childbirth and postpartum, to humanized abortion care provided by Law, care for Sexually Transmitted Infections (STI) and other reproductive disorders involving all populations, including Lesbian, Gay, Bisexual, Transvestite, Transgender, Transgender or Intersex (LGBTI) and others in vulnerable situations; to the promotion of human sexuality; to the strengthening of the exercise of responsible parenthood, as well as referral and guidance on appropriate treatment in cases of infertility. It is, therefore, a broad spectrum of care to be provided without distinction of race, religious belief, sexual orientation and age..$^{4,5}$

Even with the existence of several Policies and Programs, including the National Policy for Integral Assistance to Women's Health ("PNAISM"), the National Policy for Integral Attention to Men's Health ("PNAISH"), Law No. 9.263 of Family Planning and Several governmental guidelines related to the sexual and reproductive health of men and women in $\mathrm{PHC}$, studies have reported a gap between the norms and guidelines and their application in care practice..$^{6-12}$

The fact that sexual and reproductive health actions are one of PHC's priority axes in the theory and guidelines of the mentioned health programs and policies does not guarantee that they will be effectively implemented in the services. In this scenario, specifically in the management of $\mathrm{PHC}$ programs and interventions, there seems to be a gap between the project expressed in the policy texts and its effective operationalization in organizational and care practices.

It is known that to ensure the effectiveness of interventions, it is important to know their implementation characteristics, that is, the degree of implementation and the factors that favor (or hinder) their internal dynamics. ${ }^{13}$ Thus, the implementation assessment can be a timely and relevant strategy for apprehending and understanding gaps, barriers and/or potentialities, thus contributing to the readjustment of work processes and improvement of care processes. ${ }^{14}$

This scope review aimed to map and characterize the researches of implementation evaluation, targeting sexual and reproductive health actions in the Brazilian primary care setting, describing the main factors favorable or not to such actions.

\section{METHODS}

The study was designed as a scoping study (or scoping review). Scope reviews allow you to broaden the overview of a particular topic and the key concepts that underlie an area of knowledge, as well as assist in examining the extent, scope and nature of investigations, summarize their findings and identify possible gaps to be addressed or deepened in further studies. ${ }^{15}$

Subject of numerous methodological advances in recent times, this type of review differs from systematic reviews because the methodological quality of the included studies is not subject to evaluation, while differing from narrative literature reviews, as the review of scope requires an analytical reinterpretation of the literature. ${ }^{16}$ The Scope Review, as a methodology to produce scientific knowledge, has had increasing use in health, especially in the international sphere. ${ }^{16}$

For the search and selection of studies, the following guiding question was established: "What are the characteristics of national studies evaluating the implementation of interventions in sexual and reproductive health in PHC, published between 1994 and January 2019?" The time frame examined was defined from the time of the implementation of the Family Health Program, as a strategy for reorganizing primary care. Coincidentally, 1994 was the year of the Cairo Conference, a meeting that became known as an international milestone for demographic and sexual and reproductive health issues.

The bibliographic databases LILACS, MEDLINE (via Pubmed), SCOPUS, Web of Science and CINAHL (Cumulative Index to Nursing and Allied Health Literature) and the specific base for reproductive health and family planning POPLINE (Population Information online) were consulted. The searches were performed between December 2018 and January 2019, using search strategies specifically developed and adapted to each database, designed with the support of a professional in the area of library science. These base-specific strategies can be obtained by consulting the authors, but generally involved research based on Health Sciences Descriptors (DeCS) and/or 
their synonyms (Reproductive Health, Reproductive Health Services, Family Planning Services, Family Planning (Public Health), Prenatal care, Reproductive Rights, Sexually Transmitted Diseases, Sexual Health, Implementation, Evaluation, Assessment, Program Evaluation, Health Services Evaluation, Health Evaluation) and in related free terms, combined with Brasil/Brazil, with the use of the Boolean operators AND, OR, and NOT. Were used as filters English, Portuguese and/or Spanish as publication languages and studies which did not involve animal studies. ENDNOTE ${ }^{\circledR}$ reference management software (online version) was used to eliminate duplicate references.

The selection was made by a single researcher, in two steps, first examining titles and abstracts and then reading the full text to apply the inclusion and exclusion criteria. Studies were selected whose objectives were to evaluate, describe or analyze the implementation or establishing in Brazil of interventions related to sexual and reproductive health, with PHC as locus. As the spectrum of interventions was not previously defined, we sought to cover all actions present in the Ministry of Health's Primary Care Instruction Manual, concerning sexual and reproductive health. ${ }^{4}$

Were excluded publications whose context of research was not exclusively the PHC or when there was no separate information for this level of care; evaluative research with a different approach to the implementation of actions; integrative, narrative and systematic reviews; experience reports or clinical cases, as well as editorials, letters, conference abstracts and documents not consistent with the theme.

We searched for references in the bibliography of eligible articles and, additionally, for complementary reference in the Brazilian Electronic Theses and Dissertations Digital Library (BETDDL), using an advanced search tool (Title: Implementation OR Title: Establishing OR Title: Evaluation) and (All fields: Reproductive health OR All fields: Sexual health OR All fields: Family planning OR All fields: Sexually transmitted diseases OR All fields: Prenatal OR All fields: Infertility) to identify theses and dissertations that did not originate published articles. Identifying the same research in both formats, we chose to use the academic product, given the possibility that it does not have the size limits of publication of scientific articles and can thus bring more useful data for the purposes of this review.

Relevant data were extracted into an electronic form built in Exce ${ }^{\circledR}$ spreadsheet, including the following information: authors, title, year of publication, journal; title, purpose of the study; study design, methodological approach; location of the research; number of PHC units; intervention and dimensions assessed; and the main results, conclusions and recommendations.

The results of the review are presented in descriptive format, using tables to synthesize data from the studies, following the recommendations of the Joanna Briggs Institute (Methodology for JBI Scoping Reviews). ${ }^{17}$ Subsequently, the comparison with the literature on the establishing evaluation subsidized the analysis.
The research waived the review by the Ethics Committee, as it used only secondary literature data.

\section{RESULTS}

The search strategies allowed to retrieve 3,788 articles and 687 theses and dissertations (academic products) in the BETDDL. Were excluded 295 duplicate articles. The pre-selection, based on the examination of titles and abstracts, resulted in the reading of the full text of 97 articles and 12 academic researches. Of these, 11 articles were included, of which six (6) had thesis and/or dissertation available and five (5), only the article. Regarding the BETDDL, three (3) academic researches were excluded and three (3) others were included, which replaced the respective included articles. Of the total corpus of 14 studies included in the review, ${ }^{18-31}$ five (5) articles and nine (9) academic researches specifically addressed the evaluation of the establishing of sexual and reproductive health actions, programs and/or practices in the context of PHC (Figure 1). No cross-references were eligible for inclusion.

The main reasons for excluding research were: another type of evaluative research (49 papers); not performed in $\mathrm{PHC}$ (18); not being an evaluative study (10); evaluative research conducted in PHC and other levels of care, however PHC data were not presented separately (eight studies), and four (4) studies were unrelated to the review theme.

The studies were published/defended in the period from 2008 to 2017 , being $64.3 \%$ before 2015 . Among the 14 included studies, most were published in public health journals. Seven (7) of the nine (9) academic products were defended in programs of public health, of which $33.3 \%$ in Oswaldo Cruz Foundation units.

There was a predominance of evaluations carried out in the Southeast (5), being two in Minas Gerais, two in São Paulo and one in Rio de Janeiro. More than $60 \%$ of the studies had as scenario four or more health units, being highlighted that there were three investigations that examined the implementation of sexual and reproductive health actions in more than $100 \mathrm{PHC}$ units. The quali-quantitative mixed approach was identified in eight (8) studies and the case study as a methodological design was used in nine (9) studies. The general characteristics of the studies are shown in Table 1.

Among the sexual and reproductive health actions that were the target of the establishing evaluation, there was a high frequency of focus on prenatal and reproductive planning (Table 2). The main focus of the evaluation was the establishing of assistance through analysis of the structure (physical installation, material and human resources and standards) and process (quality, compliance, access, availability).

The establishing analysis was present in ten (10) of the 14 selected studies, with the others concerning the establishing degree. The analysis of the establishing of prenatal care was performed by four (4) studies. ${ }^{18-21}$ 
Figure 1. Flowchart of article selection steps.
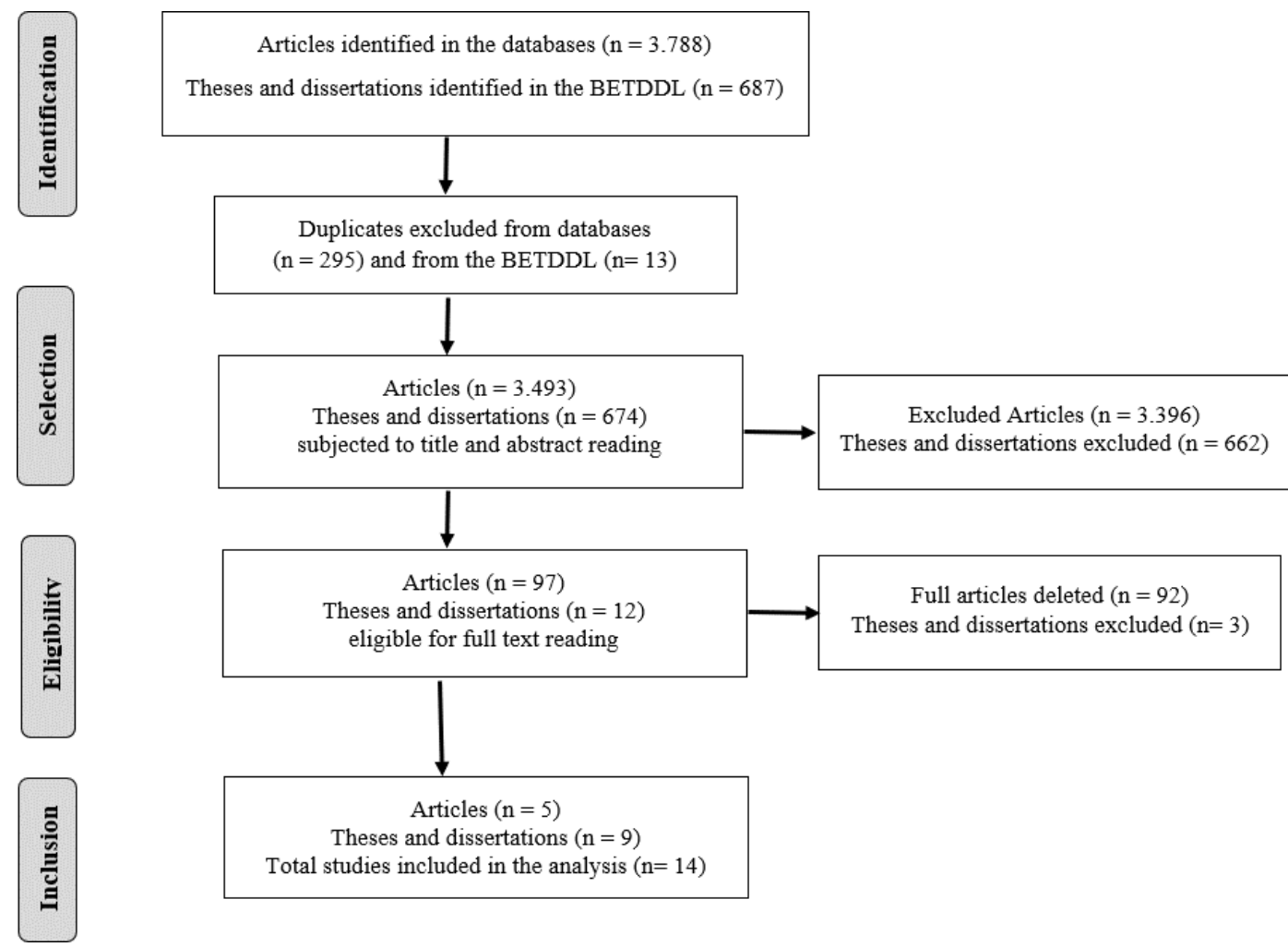

Table 1. Main characteristics of the researches included in the review ( $n=14$ studies)

\begin{tabular}{llc}
\hline Characteristics & N & $\%$ \\
\hline Year of Publication & 3 & 21.4 \\
\hline 2008 & 2 & 14.3 \\
2009 & 3 & 21.4 \\
2010 & 1 & 7.1 \\
2014 & 2 & 14.3 \\
2015 & 2 & 14.3 \\
2016 & 1 & 7.1 \\
2017 & & 35.7 \\
\hline Product type & 5 & 64.3 \\
\hline Scientific article & 9 & 7.14 \\
Theses and dissertations & & 7.14 \\
\hline Periodic & 1 & 7.14 \\
\hline Public Health Magazine & 1 & 7.14 \\
Brazilian Journal of Maternal and Child Health & 1 & 7.14 \\
Science and Collective Health & 1 & \\
Public Health Instruction Manual & 1 & \\
Care Research Magazine is Fundamental (online) & & \\
\hline
\end{tabular}




\section{Continuation Table 1.}

\begin{tabular}{|c|c|c|}
\hline Characteristics & $\mathbf{N}$ & $\%$ \\
\hline \multicolumn{3}{|l|}{ HEI, Academic Product Type, and Graduate Program Area } \\
\hline Fiocruz, MD, Public Health & 3 & 21.4 \\
\hline Universidade Fortaleza, MD, Public Health & 1 & 7.14 \\
\hline Universidade Federal da Bahia, MD, Public Health & 1 & 7.14 \\
\hline Universidade Federal do Amazonas, MD, Nursing & 1 & 7.14 \\
\hline Universidade Estadual de Ponta Grossa, MD, Social Sciences & 1 & 7.14 \\
\hline Universidade São Paulo, MD, Preventive Medicine & 1 & 7.14 \\
\hline Universidade São Paulo, DO, Preventive Medicine & 1 & 7.14 \\
\hline \multicolumn{3}{|l|}{ Region and location of study } \\
\hline North (Palmas) & 1 & 7.14 \\
\hline Northeast (Ilhéus, Fortaleza) & $\mathrm{S}$ & 14.3 \\
\hline Southeast (São Paulo, Rio de Janeiro and Minas Gerais) & 5 & 35.7 \\
\hline Midwest (Cuiabá) & 2 & 14.3 \\
\hline South (Ponta Grossa, Maringá) & 2 & 14.3 \\
\hline National & 2 & 14.3 \\
\hline \multicolumn{3}{|l|}{ Number of PHC Units involved } \\
\hline Uninformed & 2 & 14.3 \\
\hline 1 Unit & 1 & 7.1 \\
\hline 2 Units & 2 & 14.3 \\
\hline 4 Units & 1 & 7.1 \\
\hline 5 a 10 Units & 2 & 14.3 \\
\hline 11-20 Units & 1 & 7.1 \\
\hline 21-50 Units & 1 & 7.1 \\
\hline 51-100 Units & 1 & 7.1 \\
\hline$>100$ Units & 3 & 21.4 \\
\hline \multicolumn{3}{|l|}{ Methodological Approach } \\
\hline Qualitative and Quantitative & 8 & 57.1 \\
\hline Qualitative & 5 & 35.7 \\
\hline Quantitative & 1 & 7.1 \\
\hline \multicolumn{3}{|l|}{ Methodological design } \\
\hline Descriptive and/or exploratory research & 2 & 14.3 \\
\hline Case study & 10 & 71.4 \\
\hline Cross-sectional study & 2 & 14.3 \\
\hline
\end{tabular}

HEI: Higher Education Institution; MD: Master's degree; DO: Doctorate.

The reproductive planning actions offered in PHC were evaluated by four (4) studies that described the establishing from the perspective of context analysis and the degree of establishing, both of educational activities and of clinical practice actions. One of the surveys conducted in the southern region of Maringá (PR) inferred that the establishing of educational and assistance activities were incipient in the locality, despite the Unit's physical structure being in conformity. ${ }^{22}$ The evaluations carried out in the states of Rio de Janeiro, São Paulo and Minas Gerais came to different results, the educational activities performed well; on the other hand, they point out limitations on the physical structure of the units and on the supply of contraceptive inputs. ${ }^{23-25}$ In general, 
Table 2. Studies included in the review according to the evaluated intervention, type of establishing analysis and main results and recommendations.

\section{Title (Year of Publication)}

National Evaluation of the Prenatal and Birth Humanization Program $(2008)^{22}$

Evaluation of the organization of assistance for sexually transmitted diseases in the basic health network of the municipality of Ilhéus (2008) ${ }^{27}$

Health care assessment of pregnant women in the context of the Family Health Program (2009) ${ }^{18}$
Evaluated intervention

\begin{tabular}{|c|c|}
\hline $\begin{array}{c}\text { Prenatal } \\
\text { Humanization and } \\
\text { Birth Program }\end{array}$ & $\begin{array}{c}\text { Establishing } \\
\text { Analysis }\end{array}$ \\
\hline
\end{tabular}

Establishing
Analysis

Evaluation of the establishing of reproductive health services in the Municipality of Maringá $(2009)^{22}$

$\begin{array}{lc}\text { Reproductive } & \text { Establishing } \\ \text { Health Service } & \text { Analysis }\end{array}$

Large municipalities have implemented the Program more easily than small municipalities. The provision of prenatal care in PHC is a facilitator for the establishing. ${ }^{21}$

Care practices had an insufficient establishing degree. Prevention actions were partially implemented. They recommend training, organization of work processes and increased provision of educational activities for STI prevention. ${ }^{27}$

Limitations in the physical structure and lack of preparation of human resources make implementation difficult. Recommend greater performance of managers, investments for training and hiring professionals. ${ }^{18}$

No PHC obtained "advanced" establishing score. Physical area and equipment obtained the highest score in the degree of establishing. The institutionalization of the evaluation of actions is recommended. ${ }^{22}$

Approach to STIs in PHC is fragmented. Insufficient structure and lack of training, despite the availability of serologies (for HIV, hepatitis B and $C$ and syphilis) and male condoms. Recommend investments in STI prevention actions. ${ }^{26}$

The intervention was classified as a critical level of establishing. Limitations on the availability of inputs and educational resources. They recommend ongoing training and awareness of PHC professionals and institutionalization of evaluation. ${ }^{28}$

Implementation of RP in the metropolitan municipality is advanced when compared to the municipalities of the interior, whose establishing is incipient. Limitations in the work process, although the units have adequate physical structure. They recommend the training of professionals and the institutionalization of evaluation. ${ }^{23}$

Adequate physical structure, however, prenatal care is only partially implemented in PHC. Difficulties in gathering pregnant women and insufficient educational resources. ${ }^{19}$ 
Continuation Table 2.

\begin{tabular}{|c|c|c|c|}
\hline Title (Year of Publication) & $\begin{array}{c}\text { Evaluated } \\
\text { intervention }\end{array}$ & Type of analysis & Key findings and recommendations \\
\hline $\begin{array}{l}\text { Evaluation of rapid prenatal } \\
\text { syphilis and HIV testing in } \\
\text { Fortaleza }(2014)^{20}\end{array}$ & $\begin{array}{l}\text { Rapid test for } \\
\text { syphilis and HIV }\end{array}$ & $\begin{array}{l}\text { Establishing } \\
\text { Analysis }\end{array}$ & $\begin{array}{l}\text { Lack of training and systematization for the } \\
\text { operationalization of the test and lack of inputs } \\
\text { make establishing difficult. They recommend } \\
\text { conducting and disseminating studies on the } \\
\text { theme, training and greater involvement of } \\
\text { professionals. }\end{array}$ \\
\hline $\begin{array}{l}\text { Family planning: quality } \\
\text { assessment in the dimensions } \\
\text { of structure, organization and } \\
\text { care }(2015)^{25}\end{array}$ & $\begin{array}{l}\text { RP structure, } \\
\text { organization and } \\
\text { assistance }\end{array}$ & $\begin{array}{l}\text { Establishing } \\
\text { Analysis }\end{array}$ & $\begin{array}{l}\text { Most services were classified as incipient due } \\
\text { to failure to establishing RP. They highlight } \\
\text { limitations in human resources and the availability } \\
\text { of contraceptive inputs, even though PHC had } \\
\text { structure and educational materials. }^{25}\end{array}$ \\
\hline $\begin{array}{l}\text { Evaluation of actions focused } \\
\text { on women's health in Primary } \\
\text { Care, Brazil, } 2014(2016)^{31}\end{array}$ & $\begin{array}{l}\text { Actions focused } \\
\text { on women's } \\
\text { health }\end{array}$ & $\begin{array}{l}\text { Establishing } \\
\text { Analysis }\end{array}$ & $\begin{array}{l}\text { Southeast Region obtained the best classification } \\
\text { in almost all thematic groups, unlike the North and } \\
\text { Northeast regions. They recommend improving the } \\
\text { planning of actions focused on women's health in } \\
\text { PHC. }{ }^{31}\end{array}$ \\
\hline
\end{tabular}

Implementation of the National Policy for Integral Attention to Men's Health ("PNAISH") in the municipality of Ponta Grossa (2016) $)^{30}$

Challenges to reduce Congenital Syphilis: evaluation of the establishing of Prenatal Actions within the Stork Network in Primary Care in Palmas (2017) ${ }^{29}$

Evaluation of the implementation of actions on sexual and reproductive health developed in primary health care services in the state of São Paulo (2015) ${ }^{24}$

$\begin{array}{cc}\text { "PNAISH" } & \text { Establishing } \\ \text { Implementation } & \text { Analysis }\end{array}$

Despite the establishing of some "PNAISH" actions, there is still little familiarity of professionals working in PHC with the theme. Recommend the training of professionals. ${ }^{30}$

AIDS: Acquired Human Immunodeficiency Syndrome; PHC: Primary Health Care; STI: Sexually Transmitted Infections; HIV: Human Immunodeficiency Virus; "PNAISH": National Policy for Integral Attention to Men's Health; RP: Reproductive Planning.

these interventions highlight that the establishing of reproductive planning depended greatly on the training of professionals and the planning and management of such assistance in the context of PHC work routine.

Two (2) studies published in 2008 focused on actions aimed at preventing Sexually Transmitted Infections (STI). One analyzed the establishing process of this prevention in the Family Health Strategy (FHS) in São Paulo, while the other evaluated the degree of implementation of assistance to STI patients in a health unit of Ilhéus (Bahia). ${ }^{26,27}$ Despite the contextual differences, both highlighted incipient establishing and similar limitations in the establishing of actions directed to STI in PHC, referring little prioritization of educational actions, absence of counseling and/or moments of dialogue with users seeking such assistance and conduct of professionals of prescriptive character, fragmented and supported by moral judgment. One study evaluated the actions to prevent vertical transmission of syphilis in prenatal care and another, the prevention of congenital syphilis within the Stork Network. Both were based on the norms and guidelines of the assistance and judged the establishing of the intervention as incipient. ${ }^{28,29}$ 
The evaluation of the establishing of the National Program of Integral Attention to Men's Health ("PNAISH") in health units of Ponta Grossa (PR), demonstrated that it was not fully implemented due to the organizational obstacles of the unit and the little knowledge of the professionals about the policy recommended actions. ${ }^{30}$ With regard to men's sexual and reproductive health actions, the research pointed to limitations due to the low demand and availability of services directed to male health promotion.

The operationalization of women's health care in PHC in Brazil was evaluated from the perspective of actions of planning, monitoring, management of care and development of actions. ${ }^{31}$ The results highlighted that the degree of establishing of these actions varied according to the regional particularities of the country. Regarding sexual and reproductive health actions, the North and Midwest regions had lower establishing percentages.

Among the recommendations, was the need for investments in training actions for professionals, in the organization of work processes and the increase of the supply of educational activities related to sexual and reproductive health (Table 2).

\section{DISCUSSION}

Evaluative research focusing on establishing analysis allows, on the one hand, to measure the influence of variation on the degree of implementation of an intervention on its effects and, on the other hand, help to appreciate the impacts of the environment and the context in which the intervention is implemented. ${ }^{32}$ From the theoretical-methodological point of view, the implementation assessment is particularly timely when interventions are considered complex and sensitive to contextual variations, such as those that were the object of the studies present in this review. ${ }^{13}$

It is noteworthy, however, the small number (only 14) of evaluative studies with emphasis on the analysis of the implementation of sexual and reproductive health actions offered in PHC. After 25 years of the implementation of the FHS in the country, studies corroborate that the evaluation of the implementation of priority actions related to sexual and reproductive health assistance, are still in small number, although very necessary, given the scope of the related actions, its complexity and the multiplicity of factors and actors involved. ${ }^{24}$

The scarcity of evaluative research related to the analysis of the actions under discussion is even more relevant considering that the search for this scope review was quite comprehensive, both in terms of the number and profile of bibliographic bases and academic products consulted, as well as the timeframe covered, initially resulting in over 4,000 references, examined one by one for their titles and abstracts. Some reasons are listed for the reduced final number. The search strategies designed were purposely very sensitive, including in the process the search for free terms in the text and not just for the descriptors, with the in- tention exactly to minimize losses of relevant studies. Most of the references initially found were not evaluative research, so they were excluded. Even when they were evaluative surveys, many corresponded to analysis types different from the implementation assessment. Moreover, in many cases the locus of study was not research conducted specifically within the PHC. Finally, sexual and reproductive health $(\mathrm{SRH})$ care practices still seem to need to be consolidated as a working object of this level of attention, and the few records of professionals about such actions make the evaluation difficult.

Approaches that combine quantitative and qualitative aspects were used by most evaluators. There is a consensus among the evaluation scholars that both are complementary with the collection of different types of data, allowing to improve the understanding of the researched problem and to make the study more consistent. ${ }^{33}$ The case study technique was the most used research strategy, considering its explanatory potentiality and the analysis of the dynamics and actors involved in the context of the intervention. ${ }^{32}$

The establishing analysis and the evaluation of the establishing degree were the methodological strategies used. The establishing analysis was applied in ten (10) researches that investigated the relationships between the establishing, the effects and the contexts in which the intervention occurs. 18,20-26,30,31 This analysis contributes to the reflection on the main challenges that should be considered to reduce the risks of failure or of limiting the effectiveness of interventions, as well as enabling the appropriateness and usefulness of evaluative research findings by managers and other stakeholders. ${ }^{34}$ Four (4) studies used the assessment of the degree of comparison between what was foreseen in the intervention documents and the actions developed in practice. ${ }^{19,27-29}$ Their results reinforce that there are still distances and obstacles to be overcome for SRH actions to be implemented in PHC.

The establishing corresponds to the concrete implementation of an intervention in a context, described by its symbolic, organizational and physical dimensions. ${ }^{32}$ The studies in this review focused mainly on the evaluation, the analysis of structural and organizational dimensions related to health care actions offered in the context of PHC, concluding that for most of the interventions evaluated, concrete or full implementation was not yet a reality.

Another aspect to be mentioned is inequality in terms of research loci, which are still regionally quite concentrated. Half of the studies were conducted in the Southeast and South regions of the country. On the one hand, this may reflect the concentration of postgraduate programs in these regions, since much of the research resulted from masters and doctoral research, even when they took the form of published articles. On the other hand, the existing regional imbalance in terms of national scientific production is known..$^{35}$ It is also noted that only one study was requested by the Ministry of Health. ${ }^{21}$ 
The PHC sexual and reproductive health care should include prenatal, delivery and postpartum; humanized abortion care laid down by law; the promotion of human sexuality; the strengthening of the exercise of responsible parenthood; guaranteeing and promoting the sexual and reproductive rights of people who are homeless, living in prisons, sex workers, young people, the elderly and the LGBTI population. ${ }^{4}$ However, implementing it universally, longitudinally and comprehensively is still a major challenge. ${ }^{36}$

In contrast to this broad scope, it was found that the focus of interventions examined by the included studies was usually restricted to some actions. Six (6) studies evaluated the implementation of prenatal care ${ }^{18-21,28,29}$ and four (4) examined the implementation of reproductive planning care. ${ }^{22-25}$ Of these, only one (1) survey evaluated all activities that make up sexual and reproductive health care; In this case, the study investigated the performance of this assistance in 2,735 services in 586 municipalities of the state of São Paulo. ${ }^{26,27}$

Establishing analysis is valuable in uncovering factors that facilitate or compromise the implementation of an intervention, favoring improvements and stimulating changes. ${ }^{32}$ Without disregarding the influences and contextual differences, and the temporality of each evaluation, but aiming to propose reflections on the data found, some of the strengths and weaknesses in implementing the actions are repeated and highlighted. Among the studies that evaluated the same intervention, even when conducted in different municipalities, the similarities between the aspects that compromised or, conversely, potentiated the implementation were recurrent.

None of the research focusing on prenatal care rated establishing as advanced. ${ }^{18-29}$ The main reasons reported for this were directly linked to inadequate, often impromptu physical structure, as well as insufficient and inadequately trained human resources. In the contexts where the physical structure was judged with advanced establishing, that is, that had sufficient rooms for attendance and availability of materials and inputs, the establishing was favored. Similarly, in contexts where there were skilled human resources and training programs, establishing was facilitated, ${ }^{20,29}$ while the opposite undermined the establishing. ${ }^{19,28}$

In this regard, it is important to remember that continuing education, used as a device to mediate changes, allows to subjects a process of self-analysis at work and, in addition to that, also of professional growth. ${ }^{37}$ However, still persist in services the difficulties to understand permanent education as a process of change, with educational actions being strongly restricted to punctual and technically oriented moments. ${ }^{37}$ The difficulties of implementing permanent education in daily work, remain a reality in $\mathrm{PHC}$ and this has been pointed out in several of the mentioned researches. It is therefore urgent to overcome the fragmented understanding of the format of continuing education, usually offered as a formal moment of one-off courses.
Structural conditions favor, but do not guarantee, the effective implementation of interventions..$^{34}$ The studies included which had focus on the evaluation of reproductive planning assistance coincidentally pointed to the existence of adequate physical structure as a favorable aspect. At the same time, they mentioned factors related to the work process - such as lack of regularity in the provision and restricted availability of contraceptives, lack of educational activities and registration tools to monitor the population's sexual and reproductive health - considered weaknesses that hinder the implementation of reproductive planning. ${ }^{22-25}$

The implementation of assistance to patients with STI in PHC was classified as insufficient by two (2) researches. ${ }^{26,27}$ Both pointed out that this insufficiency was related to gaps in care practice, such as knowledge of protocols and failures in individual and collective counseling, besides low prioritization of educational actions with little availability of educational materials. The increased availability of serology for human immunodeficiency virus, hepatitis $\mathrm{B}$ and $\mathrm{C}$, and syphilis, as well as the supply of male condoms, were scored as advances in the implementation of care. ${ }^{26}$

Educational practices in the area of reproductive planning assistance and prenatal care were recurrently mentioned as a primary component in $\mathrm{PHC}$ care practice, being evaluated as incipient, routinely relegated to the background in action planning and with prescriptive approaches. ${ }^{18,22-24}$

One of "PNAISH"'s proposals is the implementation of actions directed to men's sexual and reproductive health, but to this end, some limitations must be overcome. According to the results of research conducted in Ponta Grossa (PR), professionals were unaware of the objectives and actions advocated by the policy, care was restricted to business hours and educational approaches limited to prostate cancer and STI. ${ }^{30}$

In another study, actions directed at women's health also presented challenges and were not fully implemented. ${ }^{31}$ The assessment based on data from PHC teams from all over the Brazilian territory, who joined the second cycle of the National Program for Improving Access and Quality of Primary Care, highlighted difficulties in monitoring of network, overwork and lack of structure, as well as low capacity of municipalities - both in planning and, in fact, in serving women in their needs. Regarding the item "care management", it was positively evaluated. ${ }^{31}$

In addition to describing the weaknesses and strengths of the implementation, the evaluators made several recommendations with the purpose of promoting changes and allowing the appropriation of study results. These recommendations usually aimed at professionals and managers, since these are the (key) actors for the establishing and implementation of actions in PHC. In this sense, the applicability of the protocols and the institutionalization of the evaluation of the services suggested 
that the responsibility was shared among the team and that all transformation began by continuous training, according to the needs of professionals and services.

Finally, the studies included in the review discussed various obstacles in the fieldwork of the research, inherent to the theoretical and methodological aspects of establishing evaluations. The following were mentioned: lack and incompleteness of records; difficulties in communicating with $\mathrm{PHC}$ professionals and managers, necessary since this is an evaluative research; use of data regarding the statements of professionals, which tend to make the situation more positive; few evaluation initiatives by the service itself, among other issues involving the political and social scenarios. ${ }^{21,24,25,29}$ The knowledge of these difficulties are useful for planning future evaluations, as well as contributing to the awareness of implications of time, context and actors involved in the evaluation process.

\section{FINAL CONSIDERATIONS}

Scope reviews are seen as a timely strategy for mapping the literature on a particular topic. For this, however, they need to be comprehensive in terms of the bases searched and the time range covered. This review covered six bibliographic databases, one of them specific to the theme, and the BETDDL, as well as a wide search range, from January 1994 to January 2019, aiming to retrieve more studies. Despite the effort, the amount of research identified was small, and may be due to the fact that experiences on the subject have not yet been published and/or are restricted to internal disclosure in institutions, especially in health services where they were conducted.

Other studies evaluating the implementation of sexual and reproductive health actions in maternity hospitals or in other contexts other than PHC should be considered. However, PHC, besides having sexual and reproductive health as one of its care priorities, is also important for the consolidation of the principles and guidelines of the Unified Health System (UHS).

The evaluation provided a reflection on the strengths and weaknesses of the implementation of sexual and reproductive health actions in PHC. Other contributions from the evaluations were the recommendations and suggestions for changes that strengthen the rationality of the external use of the evaluation.

Finally, it is suggested that the assessment is henceforth a strengthening instrument for the implementation of other interventions in the field of sexual and reproductive health in $\mathrm{PHC}$, such as care for infertility, sexuality, abortion, puerperal care, sexual and reproductive health of men, adolescents and the LGBTI population.

\section{FINANCING}

The present work was carried out with the support of the Higher Education Personnel Improvement Coordination - Brazil (Coordenação de Aperfeiçoamento de Pessoal de Nível
Superior - CAPES) - Financing Code 001, PhD scholarship granted to Carla Cardi Nepomuceno de Paiva.

\section{REFERENCES}

1. Silva RR, Gasparini MFV, Barboza M. Avaliações sob medida: Produzir Estudos Relevantes em Serviços de Saúde Reais. In: Tanaka OY, Ribeiro EL, Almeida CAL, organizadores. Avaliação em Saúde: Contribuições para Incorporação no Cotidiano. Rio de Janeiro: Atheneu; 2017. p.11-27.

2. Ministério da Saúde (BR). Portaria n. 2.436, de 21 de setembro de 2017. Aprova a Política Nacional de Atenção Básica, estabelecendo a revisão de diretrizes para a organização da Atenção Básica, no âmbito do Sistema Único de Saúde (SUS). Diário Oficial da União, Brasília (DF). 21 set 2017; [cited 2019 jan 22]. Available from: http://bvsms. saude.gov.br/bvs/saudelegis/gm/2017/prt2436_22_09_2017.html

3. Cook RJ, Dickens BM, Fathalla MF. Saúde reprodutiva e direitos humanos: integrando medicina, ética e direito. Rio de Janeiro (RJ) CEPIA; 2000.

4. Ministério da Saúde (BR). Secretaria de Atenção à Saúde. Departamento de Atenção Básica. Cadernos de Atenção Básica - Saúde sexual e saúde reprodutiva. Brasília (DF): Ministério da Saúde; 2013.

5. Organização das Nações Unidas (ONU). Relatório da Conferência Internacional sobre população e Desenvolvimento. Plataforma de Cairo Cairo: Fundo de População das Nações Unidas (UNFPA-Brasil); 1994; [cited 2019 jan 10]. Available from: http://www.unfpa.org.br/Arquivos/ relatorio-cairo.pdf

6. Ministério da Saúde (BR). Assistência Integral à Saúde da Mulher: Bases de Ação Programática. Brasília (DF): Ministério da Saúde; 1985.

7. Ministério da Saúde (BR). Secretaria de Atenção à Saúde. Departamento de Ações Programáticas Estratégicas. Política nacional de atenção integral a saúde do homem - princípios e diretrizes. Brasília (DF): Ministério da Saúde; 2008.

8. Lei n. 9.263 de 12 de janeiro de 1996 (BR). Regula o $\S 7^{\circ}$ do art. 226 da Constituição Federal, que trata do planejamento familiar, estabelece penalidades e dá outras providências. Diário Oficial da União, Brasília (DF), 15 jan 1996: Seção 1; [cited 2019 jan 15]. Available from: http:// www.planalto.gov.br/ccivil_03/leis/19263.htm

9. Ministério da Saúde (BR). Instituto Sírio-Libanês de Ensino e Pesquisa. Protocolos da Atenção Básica: Saúde das Mulheres. Brasília (DF): Ministério da Saúde; 2016.

10. Ministério da Saúde (BR). Saúde Sexual e Saúde Reprodutiva: os homens como sujeitos de cuidado. Brasília (DF): Ministério da Saúde; 2018.

11. Nasser MA, Nemes MI, Andrade M, Prado R, Castanheira E. Assessment in the primary care of the State of São Paulo, Brazil: incipient actions in sexual and reproductive health. Rev Saúde Pública [Internet]. 2017; [cited 2019 jan 20]; 51:77. Available from: http://doi. org/10.11606/s1518-8787.2017051006711

12. Dias MG, Santos JS, Almeida DR, Rocha FC, Andrade Neto GR, Andrade DLB. Participação masculina no planejamento familiar. HU Revista [Internet]. 2017; [cited 2019 jan 20]; 43(4):349-354. Available from: http://periodicos.ufj.br/index.php/hurevista/article/view/13866

13. Hartz ZMA. Avaliação em Saúde: dos modelos conceituais à prática na análise da implantação de programas. Rio de Janeiro: Editora FIOCRUZ; 1997.

14. Medina MG, Aquino R, Vilasbôas ALQ, Nunes CA, Prado NMBL. Atenção primária à saúde: reflexões sobre a política a partir da prática de pesquisa. In:Teixeira CF. Observatório de Análise Política em Saúde: abordagens, objetos e investigações. $1^{\underline{a}}$ ed. Salvador: EDUFBA;2016.

15. Peterson J, Pearce P, Ferguson L, Langford CA. Understanding scoping reviews: Definition, purpose, and process. J Am Assoc Nurse Pract [Internet]. 2017 jan; [cited 2019 jan 10]; 29(1):12-16. Available from: https://onlinelibrary.wiley.com/doi/pdf/10.1002/2327-6924.12380 DOI: http://doi.org/10.1002/2327-6924.12380 
16. Levac D, Colquhoun $H$, O'Brien KK. Scoping studies: advancing the methodology. Implementation Science [Internet]. $2010 \mathrm{sep}$; [cited 2019 jan 20]; 5(1):69. Available from: https://implementationscience. biomedcentral.com/articles/10.1186/1748-5908-5-69

17. Joanna Briggs Institute (JBI). JBI Reviewers Manual: Methodology for JBI-Scoping Reviews [Internet]. Australia: JBI; 2015; [cited 2019 mar 19]. Available from: http://joannabriggs.org/assets/docs/sumari/ Reviewers-Manual_Methodology-for-JBI-Scoping-Reviews_2015_ v2.pdf

18. Costa GD, Cotta RMM, Reis JR, Siqueira-Batista R, Gomes AP, Franceschini SCC. Avaliação do cuidado à saúde da gestante no contexto do Programa Saúde da Família. Ciênc Saúde Coletiva [Internet]. 2009; [cited 2019 jan 10]; 14(Suppl 1):1347-57. Available from: http://www.scielo.br/scielo.php?script=sci_arttext\&pid=S1413$81232009000800007 \&$ Ing =en

19. Handell IBS. Avaliação da implementação da Assistência Pré-Natal no município de Cuiabá: um estudo de caso [dissertação]. Rio de Janeiro (RJ): Mestrado em Saúde Pública, Escola Nacional de Saúde Pública Sérgio Arouca, Fundação Instituto Oswaldo Cruz; 2010.

20. Lopes ACMU. Avaliação da implantação dos testes rápidos para sífilis e HIV no pré-natal em Fortaleza [dissertação]. Fortaleza (CE): Mestrado em Saúde Coletiva, Universidade de Fortaleza; 2014.

21. Ministério da Saúde (BR). Departamento de Ciência e Tecnologia, Secretaria de Ciência, Tecnologia e Insumos Estratégicos. Avaliação nacional do Programa de Humanização do Pré-natal e Nascimento. Rev Saúde Pública [Internet]. 2008 apr; [cited 2019 jan 20]; 42(2):38387. Available from: http://www.scielo.br/scielo.php?script=sci_ arttext\&pid=S0034-89102008000200029\&/ng=en

22. Nagahama EEl. Avaliação da implantação de serviços de saúde reprodutiva no Município de Maringá, Paraná, Brasil. Cad Saúde Pública [Internet]. 2009; [cited 2019 jan 20]; 25(Suppl 2):s279-s290. Available from: http://www.scielo.br/scielo.php?script=sci_arttext\&pid=S0102311X2009001400010\&lng=en DOI: https://doi.org/10.1590/S0102311X2009001400010

23. Bonan C, Silva KS, Sequeira ALT, Fausto MCR. Avaliação da implementação da assistência ao planejamento reprodutivo em três municípios do Estado do Rio de Janeiro entre 2005 e 2007. Rev Bras Saúde Matern Infant [Internet]. 2010 nov; [cited 2019 jan 20]; 10(Suppl 1):S107-S118. Available from: https://www.arca.fiocruz.br/handle/ icict $/ 1743$

24. Nasser MA. Avaliação da implementação de ações em saúde sexual e reprodutiva desenvolvidas em serviços de atenção primária à saúde no estado de São Paulo [tese]. São Paulo (SP): Doutorado em Medicina Preventiva, Universidade de São Paulo; 2015. Available from: http:// www.teses.usp.br/teses/disponiveis/5/5137/tde-22012016-110316/ pt-br.php

25. Fiuza ESS, Rocha JFD, Carneiro JA, Costa FM. Planejamento familiar: avaliação da qualidade nas dimensões da estrutura, organização e assistência. R Pesq Cuid Fundam [Internet]. 2015 oct/dec; [cited 2019 jan 21]; 7(4):3227-38. Available from: https://www.redalyc.org/articulo. oa? id $=505750948008$
26. Ferraz DAS. Avaliação da implantação de ações de prevenção das DST/Aids numa unidade de saúde da família [dissertação]. São Paulo (SP): Mestrado em Medicina Preventiva, Universidade de São Paulo; 2009. Available from: https://www.teses.usp.br/teses/ disponiveis/5/5137/tde-16062009-151622/publico/DulceFerraz.pdf

27. Cordeiro TMO. Avaliação da Organização da Assistência às Doenças Sexualmente Transmissíveis na Rede Básica de Saúde do município de llhéus/BA [dissertação]. Rio de Janeiro (RJ): Mestrado em Vigilância em Saúde e Avaliação de Programas de Controle de Processos Endêmicos, Fundação Instituto Oswaldo Cruz; 2008. Available from: https://www.arca.fiocruz.br/handle/icict/5010

28. Lopes MH. Avaliação da implementação das ações de prevenção da transmissão vertical de sífilis no pré-natal em Unidades de Saúde da Família de Cuiabá [dissertação]. Rio de Janeiro (RJ): Mestrado em Saúde Pública, Fundação Oswaldo Cruz; 2010.

29. Montalvão AS. Desafios para redução da Sífilis Congênita: avaliação da implantação das Ações do Pré-Natal no âmbito da Rede Cegonha na Atenção Básica em Palmas Tocantins [dissertação]. Salvador (BA): Mestrado profissional em Saúde Coletiva, Universidade Federal da Bahia; 2017.

30. Alves FK. Implementação da Política Nacional de Atenção Integral à Saúde do Homem (PNAISH) no município de Ponta Grossa - Paraná [dissertação]. Ponta Grossa (PR): Mestrado em Ciências Sociais Aplicadas, Universidade Estadual de Ponta Grossa; 2016. Available from: http://tede2.uepg.br/jspui/handle/prefix/248

31. Bezerra KA. Avaliação das ações voltadas à Saúde da Mulher na Atenção Básica, Brasil, 2014 [dissertação]. Manaus (AM): Mestrado em Enfermagem, Universidade Federal do Amazonas; 2016.

32. Brouselle A, Champagne F, Contandriopoulos AP, Hartz Z, Denis JL. Apreciação de Implantação. In: Brousselle A, Champagne $F$ Contandriopoulos AP, Hartz Z, organizadores. Avaliação: Conceitos e métodos. Rio de Janeiro: Fundação Oswaldo Cruz; 2011. p. 292.

33. Figueiró ACF, Frias PG, Navarro LM. Avaliação em saúde: conceitos básicos para a prática nas instituições. In: Samico I, Felisberto $E$, Figueiró AC, Frias PG, organizadores. Avaliação em Saúde: Bases Conceituais e Operacionais. Rio de Janeiro: MedBook; 2010.

34. Silva LMV. Avaliação de políticas e programas de saúde. $22^{\mathrm{a}}$ ed. Rio de Janeiro: Editora Fiocruz; 2014.

35. Sidone OJG, Haddad EA, Mena-Chalco JP. A ciência nas regiões brasileiras: evolução da produção e das redes de colaboração científica. Transinformação [Internet]. 2016; [cited 2019 jan 24]; 28(1):15-32 Available from: https://dx.doi.org/10.1590/2318-08892016002800002

36. Telo SV, Witt RR. Saúde sexual e reprodutiva: competências da equipe na Atenção Primária à Saúde. Ciênc Saúde Coletiva [Internet]. 2018 nov; [cited 2019 feb 10]; 23(11):3481-90. Available from: http://www.scielo.br/scielo.php?script=sci_arttext\&pid=S1413$81232018001103481 \& \operatorname{lng}=\mathrm{pt}$

37. Campos KFC, Sena RR, Silva KL. Educação permanente nos serviços de saúde. Esc Anna Nery [Internet]. 2017; [cited 2019 jan 20]; 21(4):e20160317. Available from: http://dx.doi.org/10.1590/2177-9465ean-2016-0317 